\title{
Prevalence and mortality of gastric and duodenal ulcers in rheumatoid arthritis-a retrospective clinicopathologic study of 234 autopsy patients
}

\begin{abstract}
Summary
Aim: The aim of this study was to determine the prevalence and mortality of gastric ( $\mathrm{gU}$ ) and duodenal (dU) peptic ulcers in rheumatoid arthritis (RA). Also, to evaluate the possible relationship between $\mathrm{gU}$ and $\mathrm{dU}$ and autoimmune vasculitis (A-SV), AA amyloidosis (AAa) or lethal septic infection (SI) with or without purulent arthritis (PA).

Patients and methods: A randomized autopsy population of 234 in-patients with RA was studied. RA was confirmed clinically according to the criteria of the ACR. The presence of $\mathrm{gU}$ and dU, A-SV, AAa, SI, or PA was determined at autopsy and supported by histological examination. The relationships between prevalence and mortality of $\mathrm{gU}$ or $\mathrm{dU}$ and $\mathrm{A}-\mathrm{SV}$, AAa, SI or PA were analyzed by Pearson's chi-squared $\left(\chi^{2}\right)$ test.

Results and conclusions: $\mathrm{gU}$ was found in $11(4.70 \%)$, dU in $9(3.85 \%)$, A-SV in 47 (20.08\%), AAa in $48(20.51 \%)$, and SI in 31 (13.24\%), accompanied with PA in $15(6.41 \%)$ of 234 patients. The negative correlation between A-SV, AAa, or PA and prevalence of $\mathrm{gU}$ or dU suggests that-in our autopsy population-A-SV, AAa or PA had no pathogenic role in development of gastric or duodenal ulcers. A-SV, AAa or PA not influenced the mortality of $\mathrm{gU}$ or dU. Gastric or duodenal ulcers can be regarded as associated diseases of RA and not as complications of it. The significant connection between SI and prevalence and mortality of $\mathrm{gU}$ or $\mathrm{dU}$ indicates a causal relationship between them: the development of $\mathrm{gU}$ or $\mathrm{dUs}$ increase the risk of lethal SI.
\end{abstract}

Keywords: rheumatoid arthritis, gastric and duodenal peptic ulcers, autoimmune vasculitis, AA amyloidosis, lethal septic infection; purulent arthritis
Volume 7 Issue I - 2017

\author{
Miklós Bély,' Ágnes Apáthy² \\ 'Department of Pathology, Hospital of the Order of the \\ Brothers of Saint John of God in Budapest, Hungary \\ ${ }^{2}$ Department of Rheumatology, St. Margaret Clinic Budapest, \\ Hungary
}

Correspondence: Miklós Bély, Department of Pathology, Hospital of the Order of the Brothers of Saint John of God in Budapest, Hungary, Email dr.bely.miklos@gmail.com

Received: April 15, 2017 | Published: June 16, 2017

\section{Introduction}

Gastric and duodenal peptic ulcers ( $\mathrm{gU}$ or $\mathrm{dU})$ are of different etiologies and are common in rheumatoid arthritis (RA). The prevalence of $\mathrm{gU}$ or $\mathrm{dU}$ is higher in RA than in the general population. ${ }^{1}$ Numerous early and recent studies discuss the relationship between $\mathrm{gU}$ or $\mathrm{dU}$ and non-steroidal anti-inflammatory drugs, ${ }^{2-5}$ corticosteroids, ${ }^{4-8}$ anticoagulants, ${ }^{6}$ with or without other contributing common factors (sex, age, smoking, alcohol consumption, etc.).The therapy induced peptic ulcers (with complications like perforations, peritonitis, septic infections or bleeding) play an important role in the mortality of RA., ${ }^{9}$ Gastrointestinal involvement by complications of RA, such as systemic vasculitis or amyloidosis - with or without peptic ulcers-is also well known. ${ }^{9-11}$ The aim of this study was to determine the prevalence and mortality of $\mathrm{gU}$ and $\mathrm{dU}$ in RA. Also, to identify the possible role of systemic autoimmune vasculitis (A-SV) or AA amyloidosis (AAa) in the prevalence and mortality of $\mathrm{gU}$ and $\mathrm{dU}$, furthermore to evaluate the possible relationship between $\mathrm{gU}$ and $\mathrm{dU}$ and lethal septic infection (SI) with or without purulent arthritis (PA).

\section{Patients and methods}

At the National Institute of Rheumatology 11558 patients died between 1969 and 1998; among them 234 with RA (females 170, average age: 66.31 years, range $88-16$, onset of RA: 50.46 , average disease duration: 12.96 years; males 64 , average age: 66.08 years, range $88-19$, onset of RA: 52.55 , average disease duration: 12.96 years at death), and all of them were autopsied.
RA was confirmed clinically according to the criteria of the American College of Rheumatology (ACR). ${ }^{12}$ The basic disease, its complication(s), and the lethal outcome caused by $\mathrm{gU}$ and $\mathrm{dU}$ were determined and analyzed retrospectively, reviewing the clinical and pathological reports. The presence of $\mathrm{gU}$ or $\mathrm{dU}$ and A-SV, AAa furthermore SI (with or without PA) was determined at autopsy and confirmed by a detailed review of extensive histological material. From each patient 50-100 tissue blocks of 12 organs (heart, lung, liver, spleen, kidneys, pancreas, gastrointestinal tract, adrenal glands, skeletal muscle, peripheral nerve, skin and brain) were studied microscopically..$^{13}$ Amyloid A deposits were diagnosed histologically according to Romhányi ${ }^{14}$ by a modified (more sensitive) Congo red staining, ${ }^{15}$ and were confirmed histochemically. ${ }^{16}$ The relationships between prevalence and mortality of $\mathrm{gU}$ or $\mathrm{dU}$ and A-SV, AAa furthermore SI (with or without PA) were analyzed by Pearson's chisquared $\left(\chi^{2}\right)$ test. $^{17}$

\section{Results}

$\mathrm{gU}$ was found in $11(4.70 \%)$, and $\mathrm{dU}$ in $9(3.85 \%)$ of $234 \mathrm{RA}$ patients (Figure 1.1). Seven $\mathrm{gU}$ of 11, and $6 \mathrm{dU}$ of 9 led to death in 13 (65.0\%) of 20 patients (Figure 1.2). In 4 patients (in 2 with $\mathrm{gU}$ and in 2 with $\mathrm{dU}$ ) the direct cause of death was massive internal bleeding, and in 3 (in 2 with $\mathrm{gU}$ and in 1 with $\mathrm{dU}$ ) it was perforation of an ulcer accompanied by peritonitis. Perforated $\mathrm{gU}(\mathrm{n}=3$ of 11$)$ and $\mathrm{dU}$ $(n=3$ of 9$)$ existed in further 6 patients with peritonitis and generalized lethal SI (the outcome of $3 \mathrm{gU}$ and $3 \mathrm{dU}$ in all of these 6 cases were lethal). In $7(35.0 \%)$ of 20 patients $4 \mathrm{gU}$ and $3 \mathrm{dU}$ existed without 
lethal complications (Figure 1.2). $\mathrm{gU}$ and $\mathrm{dU}$ (with or without lethal outcome) were recognized clinically in 14 (in 8 with $\mathrm{gU}$ and in 6 with $\mathrm{dU} ; 70.0 \%$ ) of 20 cases, and missed in 6 (in 3 with $\mathrm{gU}$ and in 3 with $\mathrm{dU} ; 30.0 \%$ ) of 20 (Figure 1.3). A-SV (Figure 2a-d) was observed in in $47(20.08 \%)$, AAa (Figure 3 \& 4$)$ in $48(20.51 \%)$, and SI in 31 (13.24\%), accompanied with PA in 15 (6.41\%) of 234 patients.

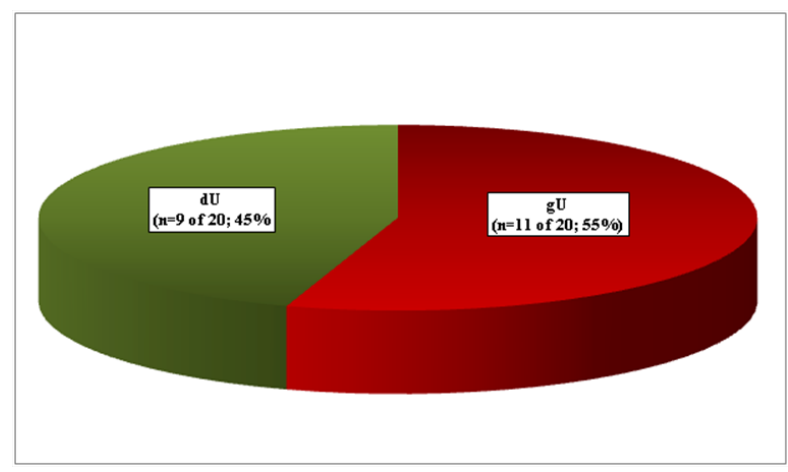

Figure I.I Prevalence of gastric $n=1$ ( $55.0 \%)$ and duodenal $n=9$ (45.0\%) peptic ulcers in 234 RA patients.

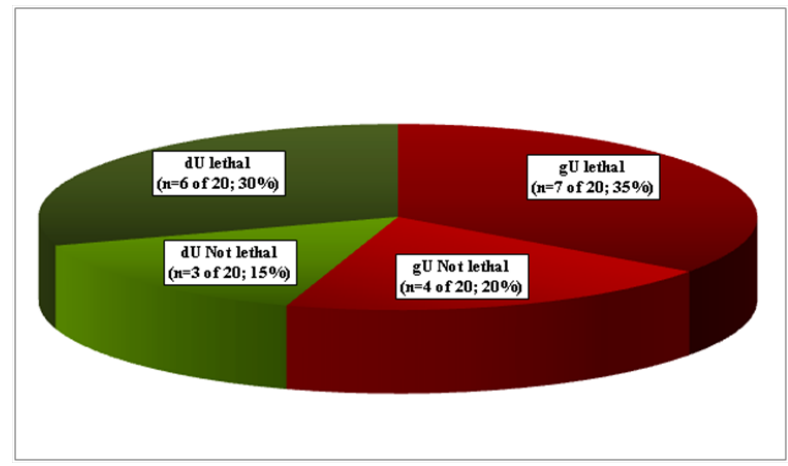

Figure I.2 Prevalence: $n=20$ (8.55\%), and mortality $n=13(5.56 \%)$ of gastric or duodenal peptic ulcers-by bleeding, peritonitis or SI- in 234 RA patients.

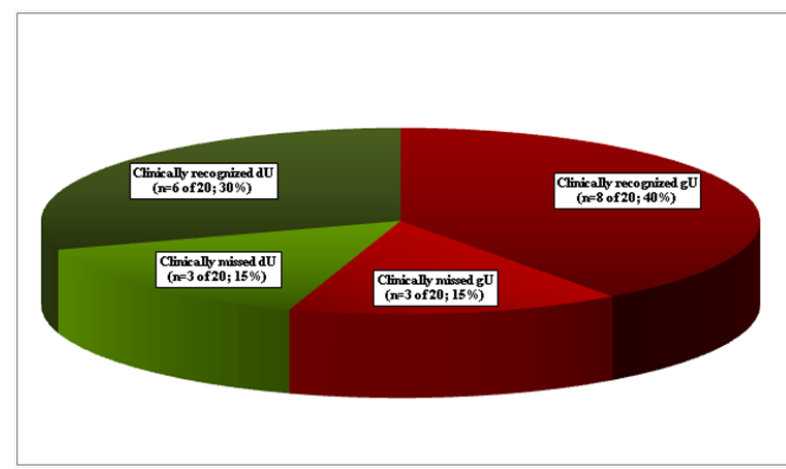

Figure I.3 Clinically recognized $n=14(70.0 \%)$ or missed $n=6(30.0 \%)$ of gastric or duodenal peptic ulcers in 234 RA patients.

Sex, average age (range) and disease duration, and onset of RA in patients with or without $\mathrm{gU}$ or $\mathrm{dU}$, and with or without A-SV, AAa, SI, or PA are summarized in Table 1. The basic disease, complication(s) and associated diseases of $20 \mathrm{RA}$ patients with $\mathrm{gU}$ or dU are summarized in Table 2. $\mathrm{gU}$ or $\mathrm{dU}$ were associated with A-SV in 3, with AAa in 3, with lethal SI in 6 of 20 patients. gU or dU with lethal outcome were associated with systemic A-SV in 3, with AAa in 3, with lethal SI in 6 of 13 patients. In this autopsy population $\mathrm{gU}$ or $\mathrm{dU}$ was never associated with PA.

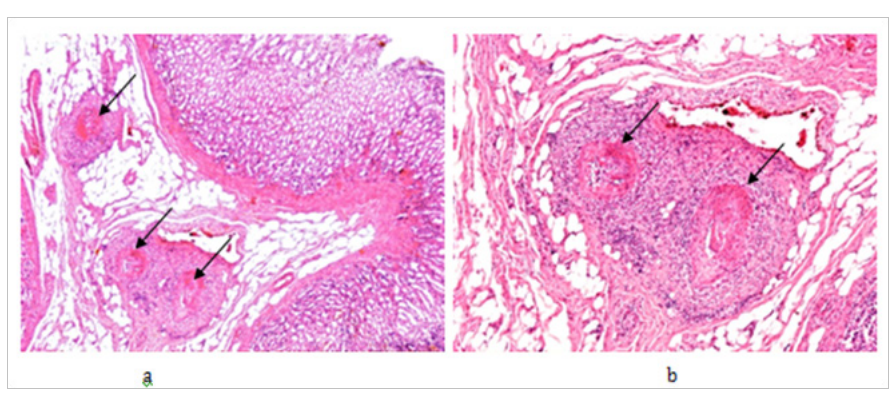

Figure 2 Rheumatoid arthritis, gastrointestinal tract (stomach), systemic vasculitis of autoimmune origin (A-SV).

Small arteries, non-specific vasculitis with sectorial fibrinoid necrosis (arrows) in subacute-subchronic stage of inflammation.

(a) HE, $\times 20$, (b) same as (a) $\times 40$, (c) and (d) same as (a) $\times 100$
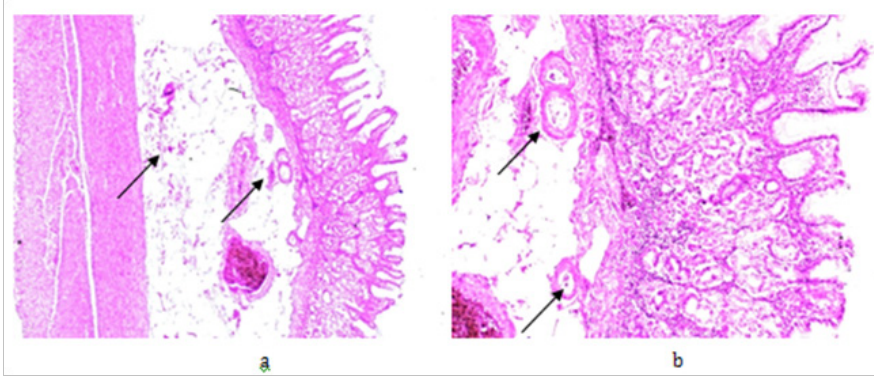

Figure 3 Rheumatoid arthritis, gastrointestinal tract (stomach), systemic secondary AA amyloidosis (AAa).

Amyloid $A$ deposits in the wall of arterioles, small arteries and within interstitial reticulin and collagen fibers (arrows).

(a) PAS, $\times 50$, (b) same as (a) $\times 125$
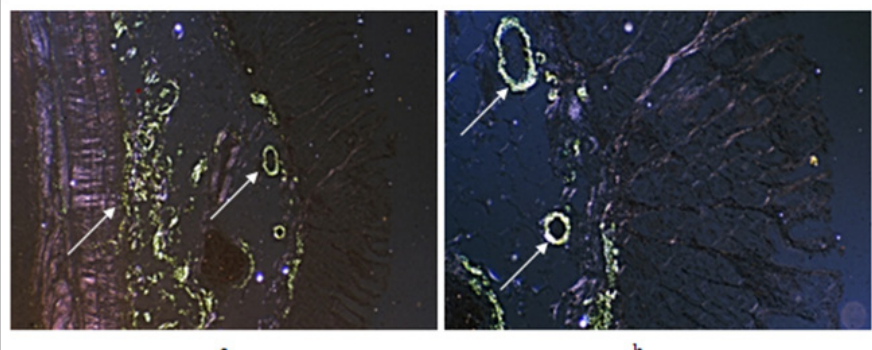

Figure 4 Rheumatoid arthritis, gastrointestinal tract (stomach), systemic secondary AA amyloidosis (AAa).

Same as Figure $3 a b$, Congo red staining, without alcoholic differentiation, covered with gum arabic. Viewed under polarized light (a) $\times 50$ (b) same as (a) $\times 125$

The relationship between $\mathrm{gU}$ or $\mathrm{dU}$ and coexistent $\mathrm{SV}$, AAa, furthermore lethal SI (with or without PA) in 234 RA patients is summarized in Table 3. There was no significant correlation between A-SV, AAa, PA and prevalence or mortality of $\mathrm{gU}$ or $\mathrm{dU}$. There was a significant correlation between SI and prevalence and mortality of gU or dU. A-SV coexisted with AAa in 9 of 47 patients. The relationship between A-SV and AAa was not significant $\left(x^{2}=0.0032, p<0.95\right)$; the A-SV did not influence the prevalence of AAa, and AAa did lead to A-SV in our autopsy population.

\section{Discussion}

Numerous publications discuss the prevalence of peptic ulcers (Table 4), vasculitis (Table 5), amyloidosis (Table 6) or lethal septic 
infection (Table 7) in RA with or without its role in mortality. ${ }^{17-55}$ Unfortunately these studies do not specify the relationship between $\mathrm{gU}$ or $\mathrm{dU}$ and A-SV, AAa or SI. In most of these early studies the prevalence or mortality of $\mathrm{gU}$ or $\mathrm{dU}$ seems to be underestimated, presumably due to the limited microscopic examination of the gastrointestinal tract.

It is difficult to estimate the true prevalence of A-SV, AAa or SI. Most studies do not specify the type of vasculitis (autoimmune, septicbacterial, viral, fungal-hypertonic, endocrine disease associated, etc.). Amyloidosis in most studies is diagnosed with different methods of diverse specificities and sensitivities (with or without identification of the types of amyloid deposits)

According to our best knowledge a detailed analysis of A-SV or AAa and its role in the prevalence and mortality of gU or dU has not been available in the literature. The negative correlation between A-SV $\left(c^{2}=0.09107, p<0.76\right)$, AAa $\left(c^{2}=0.1217, p<0.72\right)$ or PA $\left(c^{2}=0.5573, p<0.45\right)$, and prevalence of $g U$ or dU suggests that-in our autopsy population - A-SV, AAa or PA had no pathogenic role in the development of gastric or duodenal ulcers.

A-SV $\left(x^{2}=0.0062, p<0.93\right)$, AAa a $\left(x^{2}=0.0138, p<0.91\right)$ or PA $\left(\mathrm{c}^{2}=0.1508, \mathrm{p}<0.69\right)$ did not influence the mortality of $\mathrm{gU}$ or $\mathrm{dU}$. Gastric or duodenal ulcers may be regarded as associated diseases of RA and not as complications. The significant correlation between $\mathrm{gU}$ or dU and lethal SI indicates a causal relationship: the development of $\mathrm{gU}$ or dUs increases the risk of lethal SI; in case of a perforated ulcer there is a direct relationship. The positive and significant correlation between SI and PA-as it was found in our previous study ${ }^{13}$-indicates also a similar causal relationship. At the same time the negative association's coefficient (-1) and lack of a significant correlation between $\mathrm{gU}$ or $\mathrm{dU}$ and PA suggests that these are individual phenomena which may exist simultaneously in RA leading to lethal SI independently from each other.

Table I Sex, average age (range), onset of disease and disease duration (in years) of RA patients with or without gU or dU and SV,AAa, SI or PA

\begin{tabular}{|c|c|c|c|c|c|}
\hline Sex & $\begin{array}{l}\text { Number of } \\
\text { Autopsies }\end{array}$ & $\begin{array}{l}\text { Average age in } \\
\text { years at Death }\end{array}$ & Range (in Years) & $\begin{array}{l}\text { Age at Onset } \\
\text { of Disease }\end{array}$ & $\begin{array}{l}\text { Disease Duration (in } \\
\text { Years) }\end{array}$ \\
\hline RA patients & 234 & 66.25 & $88-16$ & 51.02 & 14.76 \\
\hline Female & 170 & 66.31 & $88-16$ & 50.46 & 15.42 \\
\hline Male & 64 & 66.08 & $88-19$ & 52.55 & 12.96 \\
\hline With gU or dU & 20 & 65.1 & $88-45$ & 51.15 & $|3.3|$ \\
\hline Female & 14 & 66 & $88-45$ & 51.44 & 12.33 \\
\hline Male & 6 & 63 & $70-48$ & 50.5 & 15.5 \\
\hline Without gU or dU & 214 & 66.36 & $88-16$ & 51.01 & 14.87 \\
\hline Female & 156 & 66.34 & $88-16$ & 50.39 & 15.65 \\
\hline Male & 58 & 66.4 & $88-19$ & 52.73 & 12.73 \\
\hline A-SV & 47 & 68.09 & $88-32$ & 55.89 & 12.8 \\
\hline Female & 29 & 68.83 & $88-32$ & 55.69 & 14.23 \\
\hline Male & 18 & 66.89 & $83-53$ & 56.17 & 10.72 \\
\hline Without A-SV & 187 & 65.78 & $88-16$ & 49.46 & 15.38 \\
\hline Female & $|4|$ & 65.79 & $88-16$ & 48.92 & 15.8 \\
\hline Male & 46 & 65.76 & $88-19$ & 51.25 & 14 \\
\hline With AAa & 48 & 63.75 & $88-19$ & 46.66 & 17.18 \\
\hline Female & 38 & 65.13 & $88-32$ & 46.54 & 17.91 \\
\hline Male & 10 & 58.5 & $88-19$ & 47.11 & 14.33 \\
\hline Without AAa & 186 & 66.9 & $88-16$ & 52.41 & 13.99 \\
\hline Female & 132 & 66.66 & $88-16$ & 51.65 & 14.56 \\
\hline Male & 54 & 67.5 & $87-20$ & 54.22 & 12.63 \\
\hline With SI & 31 & 62.45 & $83-41$ & 49.59 & 13 \\
\hline Female & 22 & 61.5 & $83-41$ & 49.53 & 12.32 \\
\hline Male & 9 & 64.78 & $71-52$ & 49.75 & 14.63 \\
\hline SI with PA & 15 & 59.47 & $71-46$ & 44.08 & 16.38 \\
\hline Female & 10 & 58.2 & $68-46$ & 42.88 & 16.63 \\
\hline Male & 5 & 62 & $57-20$ & 46 & 16 \\
\hline SI without PA & 16 & 65.25 & $83-4 I$ & 54.71 & 9.86 \\
\hline
\end{tabular}


Table continued..

\begin{tabular}{llllll}
\hline Sex & $\begin{array}{l}\text { Number of } \\
\text { Autopsies }\end{array}$ & $\begin{array}{l}\text { Average age in } \\
\text { years at Death }\end{array}$ & Range (in Years) & $\begin{array}{l}\text { Age at Onset } \\
\text { of Disease }\end{array}$ & $\begin{array}{l}\text { Disease Duration (in } \\
\text { Years) }\end{array}$ \\
\hline Female & 12 & 64.25 & $83-41$ & 54.36 & 9.18 \\
Male & 4 & 68,3 & $70-66$ & 56 & 12.33 \\
Without SI & 203 & 66,1 & $88-16$ & 51,1 & 14,9 \\
Female & 148 & 66,1 & $88-16$ & 49,9 & 15,9 \\
Male & 55 & 66,3 & $87-19$ & 54,1 & 12,5 \\
Without & 121 & 68.01 & $88-16$ & 51.77 & 15.1 \\
Complications & 92 & 67.59 & $88-16$ & 50.44 & 15.56 \\
Female & 29 & 70,3 & $87-20$ & 56.28 & 13.56 \\
Male & & & & \\
\hline
\end{tabular}

Table 2 Prevalence and mortality of gastric or duodenal peptic ulcers in 20 of 234 RA patients

\begin{tabular}{|c|c|c|c|c|c|c|c|c|}
\hline \multicolumn{2}{|c|}{$\begin{array}{l}\text { Basic } \\
\text { Disease }\end{array}$} & \multicolumn{2}{|c|}{ Complication (1-2) } & \multirow{2}{*}{$\begin{array}{l}\text { Complication (3) } \\
\text { Gastrectomy }\end{array}$} & \multirow{2}{*}{$\begin{array}{l}\text { Cause of Death } \\
\text { Bronchopneumonia }\end{array}$} & \multirow{2}{*}{$\begin{array}{l}\begin{array}{l}\text { Associated } \\
\text { Disease(s) }\end{array} \\
\text { Ath-DM }\end{array}$} & \multirow{2}{*}{$\begin{array}{l}\mathrm{Cl}+\mathrm{Cl}- \\
\mathrm{Cl} *\end{array}$} & \multirow{2}{*}{$\begin{array}{l}\text { Protocol n/Year } \\
278 / 7 \mid\end{array}$} \\
\hline I & RA & & Gastric ulcer I-Perforation & & & & & \\
\hline 2 & RA & & Gastric ulcer2-Colitis & Perforation & Peritonitis- Lethal SII & Ath-DM & $\mathrm{Cl}-$ & $228 / 72$ \\
\hline 3 & RA & & Felty Syndrome-Splenectomy & Duodenal ulcer I & $\begin{array}{l}\text { Massive internal } \\
\text { bleeding I }\end{array}$ & $\begin{array}{l}\text { Liver necrosis } \\
\text { (red) }\end{array}$ & $\mathrm{Cl}^{*}$ & $320 / 72$ \\
\hline 4 & Ath & & Thrombosis of femoral vein & Gastric ulcer3 & Pulmonary embolism & RA-DM5 & $\mathrm{Cl}^{*}$ & $51 / 74$ \\
\hline 5 & RA & & Gastric ulcer4-Bleeding & Gastrectomie & Circulatory failure & Ath & $\mathrm{Cl} *$ & $334 / 75$ \\
\hline 6 & RA & & Nephritis & $\begin{array}{l}\text { Gastritis and } \\
\text { Duodenal ulc2 }\end{array}$ & Uraemia- Bleeding2 & & $\mathrm{Cl}^{*}$ & $197 / 76$ \\
\hline 7 & Ath & & Myocardial fibrosis & Duodenal ulcer3 & $\begin{array}{l}\text { Purulent bronchitis } \\
\text { and bronchiolitis }\end{array}$ & $\begin{array}{l}\text { RA-TbF- } \\
\text { Meningeoma }\end{array}$ & $\mathrm{Cl}-$ & $318 / 76$ \\
\hline 8 & Ath & & Myocardial fibrosis & Gastric ulcer5 & Circulatory failure & RA & $\mathrm{Cl}^{*}$ & $386 / 76$ \\
\hline 9 & RA & AAI & Gastric ulcer6-Perforation & Peritonitis & Lethal SI2 & & $\mathrm{Cl}-$ & $162 / 78$ \\
\hline 10 & RA & & Duodenal ulcer4-Colitis & & Lethal SI3 & & $\mathrm{Cl}-$ & $243 / 78$ \\
\hline II & RA & & Erosive gastritis7 & & $\begin{array}{l}\text { Massive internal } \\
\text { bleeding3 }\end{array}$ & Ath & $\mathrm{Cl}^{*}$ & $327 / 78$ \\
\hline 12 & RA & & Duodenal ulcer5 & & Circulatory failure & $\begin{array}{l}\text { DM-Hepatic } \\
\text { cirrhosis }\end{array}$ & $\mathrm{Cl} *$ & $385 / 78$ \\
\hline 13 & RA & AA2 & Duodenal ulcer6-Perforation & & Peritonitis & & $\mathrm{Cl}^{*}$ & $76 / 79$ \\
\hline 14 & RA & & Ulcerative gastritis8-Colitis & $\begin{array}{l}\text { Diverticulitis of } \\
\text { Colon-Perforation }\end{array}$ & Lethal SI4 & & $\mathrm{Cl}-$ & $55 / 82$ \\
\hline 15 & RA & SVI & Duodenal ulcer7-Perforation & Peritonitis & Lethal SI5 & Ath & $\mathrm{Cl}-$ & $318 / 89$ \\
\hline \multirow[t]{2}{*}{16} & RA & & Gastric ulcer9 & Perforation- & $\begin{array}{l}\text { Peritonitis (local) - } \\
\text { Circulatory failure }\end{array}$ & JCA & $\mathrm{Cl} *$ & $25 / 90$ \\
\hline & RA & & Gastric ulcer I0 & Perforation & Peritonitis & & $\mathrm{Cl} *$ & $205 / 91$ \\
\hline 18 & RA & & Gastric ulcer I I- Perforation & $\begin{array}{l}\text { Atlantoaxial } \\
\text { subluxation }\end{array}$ & Peritonitis & $\mathrm{HT}$ & $\mathrm{Cl}^{*}$ & $208 / 93$ \\
\hline 19 & RA & SV2 & & $\begin{array}{l}\text { Duodenal ulcer8- } \\
\text { Perforation }\end{array}$ & Lethal SI5 & TbFc & $\mathrm{Cl}^{*}$ & $375 / 95$ \\
\hline 20 & RA & SV3 & AA2 & Duodenal ulcer9 & Massive internal bleed & & $\mathrm{Cl} *$ & $33 / 96$ \\
\hline
\end{tabular}

Table 3 Relationship between prevalence and mortality of $\mathrm{gU}$, or $\mathrm{dU}$ and coexistent $\mathrm{SV}, \mathrm{AAa}$, furthermore $\mathrm{SI}$ (with or without PA) in $234 \mathrm{RA}$ patients $(\mathrm{P}<0.05$ )

\begin{tabular}{lll}
\hline Prevalence of Complications in 234 RA pts. & Prevalence of $\mathbf{g U}$ or $\mathbf{d U} \mathbf{n}=\mathbf{2 0}$ & Mortality of $\mathbf{g U}$ or $\mathbf{d U} \mathbf{n = 1 3}$ \\
\hline A-SV $n=47$ & $\chi^{2}=0.09107^{*}, \mathrm{p}<0.76$ & $\chi^{2}=0.0062, \mathrm{p}<0.93$ \\
AAa $n=48$ & $\chi^{2}=0.1217^{*}, \mathrm{p}<0.72$ & $\chi^{2}=0.0138, \mathrm{p}<0.91$ \\
Lethal septic infection $\mathrm{n}=31$ & $\chi^{2}=5.3400, \mathrm{p}<0.02$ & $\chi^{2}=12.9685, \mathrm{p}<0.0003$ \\
Purulent arthritis $\mathrm{n}=15$ & $\chi^{2}=0.5573^{*}, \mathrm{p}<0.45$ & $\chi^{2}=0.1508^{*}, \mathrm{p}<0.69$ \\
\hline
\end{tabular}


Table 4 Prevalence and mortality of peptic ulcers in autopsy material of rheumatoid arthritis

\begin{tabular}{|c|c|c|c|c|}
\hline Authors & Reference Year of Publication & $\begin{array}{l}\text { Autopsy } \\
n=\end{array}$ & $\begin{array}{l}\text { Prevalence of } \mathrm{gU} \text { or } \mathrm{dU} \\
\mathbf{N}-\%\end{array}$ & $\begin{array}{l}\text { Mortality of gU or dU } \\
\text { N - \% }\end{array}$ \\
\hline Baggenstoss and Rosenberg & $1943[17]$ & 30 & ND & $2 *-6.66 \%$ \\
\hline Rosenberg and Baggenstoss & $1943[18]$ & 30 & ND & $2 *-6.66 \%$ \\
\hline Young and Schwedel & $1944[19]$ & 33 & $0-0 \%$ & $0-0 \%$ \\
\hline Teilum and Lindahl & $1954[20]$ & 28 & $0-0 \%$ & $0-0 \%$ \\
\hline Gedda & $1955[21]$ & 45 & ND & $0-0 \%$ \\
\hline Sinclair and Cruickshank & $1956[22]$ & 16 & $4 * *-25.0 \%$ & $0-0 \%$ \\
\hline Leboowitz & $1963[23]$ & 62 & $1-1.61 \%$ & $1-1.61 \%$ \\
\hline Ozdemir et al. & 197| [24] & 47 & $16-34.04 \%$ & ND \\
\hline Püschel & $1973[25]$ & 143 & $28-19.58 \%$ & $13-9.09 \%$ \\
\hline Eulderink & $1976[26]$ & III & ND & $0-0 \%$ \\
\hline Suzuki et al. & 1994 [27] & 81 & ND & $2-2.47 \%$ \\
\hline Bély and Apáthy & $2007[28]$ & 161 & $14-8.69 \%$ & $9-5.59 \%$ \\
\hline Bély and Apáthy & 2017 [29] & 234 & $20-8.54 \%$ & $13-5.55 \%$ \\
\hline
\end{tabular}

Remarks to Table 4

ND No Data

*mentioned as gastrointestinal diseases

** caused by marked intestinal amyloidosis

Footnote to Table 4

* Negative value of association's coefficient; Significant value is in bold

Table 5 Prevalence and mortality of systemic vasculitis (SV) at autopsy of RA patients (no mention of the origin of SV)

\begin{tabular}{|c|c|c|c|c|}
\hline Authors & Year of Publication, References & $\begin{array}{l}\text { Autopsy } \\
n=\end{array}$ & $\begin{array}{l}\text { Prevalence of Vasculitis } \\
n-\%\end{array}$ & $\begin{array}{l}\text { Mortality of Vasculitis } \\
n-\%\end{array}$ \\
\hline Cruickshank & $1954[30]$ & 72 & $18-25 \%$ & ND \\
\hline Sinclair and Cruickshank & 1956 [22] & 16 & $9-56.3 \%$ & ND \\
\hline Cruickshank* & $1958[3 \mid]$ & 100 & $20 *-20 \%$ & ND \\
\hline Lebowitz & 1963 [23] & 62 & $6-10 \%$ & ND \\
\hline Sokoloff & 1964 [32] & 19 & $2-10.5 \%$ & ND \\
\hline Karten** & $1969[33]$ & 102 & $6 * *-6 \%$ & ND \\
\hline Gardner & $1972[34]$ & 142 & $7-4.9 \%$ & ND \\
\hline Davis and Engleman & 1974 [35] & 62 & $6-10 \%$ & ND \\
\hline Eulderink & $1976[26]$ & III & ND & $7-6.3 \%$ \\
\hline Albada-Kuipers et al. & $1986[36]$ & 173 & $17-10 \%$ & ND \\
\hline Boers et al. & $1987[37]$ & 132 & $18-13.6 \%$ & ND \\
\hline Suzuki et al. & 1994 [27] & 81 & $25-30.8 \%$ & ND \\
\hline Bély and Apáthy**** & $1993[38]$ & 161 & $36-22.4 \%$ & $19-11.8 \%$ \\
\hline Bély and Apáthy*** & 2006 [39] & 234 & $51-21.8$ & $23-9.8 \%$ \\
\hline
\end{tabular}

Remarks to Table 5

ND No Data

*Coronaritis

** 102 patients with RA-partially autopsied (Karten)

****The studies discuss 36 SV-33 of autoimmune origin and 3 of septic origin.

****The studies discuss 5 I SV- 47 of autoimmune origin and 4 of septic origin; the latter 4 SV of septic origin have been excluded in the present study. 
Table 6 Prevalence and mortality of AA amyloidosis in autopsy material of rheumatoid arthritis (identified amyloid deposits by different staining methods, such as:Toluidine blue, Crystal violet, Syrius red, Congo-red staining according to Romhányi, Bennhold's, Puchtler's, Bély's Congo red method)

\begin{tabular}{|c|c|c|c|c|}
\hline Authors & $\begin{array}{l}\text { Year of Publication } \\
\text { References }\end{array}$ & $\begin{array}{l}\text { Autopsy } \\
n=\end{array}$ & $\begin{array}{l}\text { Prevalence of Amyloidosis } \\
\mathbf{n}-\%\end{array}$ & $\begin{array}{l}\text { Mortality of Amyloidosis } \\
n-\%\end{array}$ \\
\hline Bayles & $1943[40]$ & 23 & ND* & $3-13.0 \%$ \\
\hline Baggenstoss and Rosenberg & $1943[17]$ & 30 & $2-6.6 \%$ & I - $3.3 \%$ \\
\hline Young and Schwedel & 1944 [19] & 33 & $5-15.2 \%$ & $0-0 \%$ \\
\hline Unger et al. & $1948[4 \mid]$ & 58 & $4-6.9 \%$ & ND \\
\hline Teilum and Lindahl & 1954 [20] & 28 & $17-60.7 \%$ & $7-25.0 \%$ \\
\hline Gedda & $1955[21]$ & 45 & II - $24.4 \%$ & $9-20.0 \%$ \\
\hline Sinclair and Cruickshank & 1956 [22] & 16 & $4-25.0 \%$ & $0-0 \%$ \\
\hline Missen and Tailor & $1956[42]$ & 47 & $8-17.0 \%$ & $4-8.5 \%$ \\
\hline Leboowitz & 1963 [23] & 62 & $6-10.0 \%$ & ND \\
\hline Sokoloff & 1964 [32] & 19 & $0-0 \%$ & $0-0 \%$ \\
\hline Cohen & $1968[43]$ & 42 & II - $26 \%$ & ND \\
\hline Karten & $1969[33]$ & 95 & I - I.05\% & ND \\
\hline Gritsman & $1969[44]$ & 15 & $6-40.0 \%$ & ND \\
\hline Ozdemir et al. & I97| [24] & 47 & $1-2.1 \%$ & ND \\
\hline Gardner & 1972 [34] & 142 & $17-11.97 \%$ & ND \\
\hline Püschel & 1973 [25] & 143 & $15-10.5 \%$ & ND \\
\hline Vroninks et al. & 1973 [45] & 62 & $3-4.84 \%$ & $062-0 \%$ \\
\hline Hajzok et al. & 1976 [46] & 16 & $7-43.7 \%$ & ND \\
\hline Eulderink & 1976 [26] & 111 & ND & $6 \mathrm{III}-5.4 \%$ \\
\hline Rainer et al. & I978 [47] & 79 & ND & $479-5.0 \%$ \\
\hline Boers et al. & I 987 [48] & 132 & $14-10.6 \%$ & ND \\
\hline Bély & I99| [49] & 161 & $34-21.1 \%$ & $17-11 \%$ \\
\hline Suzuki et al. & 1994 [27] & 81 & $17-21.0 \%$ & $6-7.4 \%$ \\
\hline Bély and Apáthy & 2006 [39] & 234 & $48-20.5 \%$ & $20-8.5 \% \%$ \\
\hline
\end{tabular}

Remarks to Table 6

ND No Data

Table 7 Prevalence of septic infection in autopsy material of rheumatoid arthritis

\begin{tabular}{lllll}
\hline Authors & Reference,Year of Publication & $\begin{array}{l}\text { Autopsy } \\
\mathbf{n}=\end{array}$ & $\begin{array}{l}\text { Clinically recognized SI } \\
\mathbf{N}-\%\end{array}$ & $\begin{array}{l}\text { Mortality of sepsis } \\
\mathbf{N}-\%\end{array}$ \\
\hline Bayles* & $1943[40]$ & 23 & ND & $2-8.7 \%$ \\
Young and Schwedel & $1944[19]$ & 33 & ND & $4-17.4 \%$ \\
Bywaters* & $1950[50]$ & 27 & ND & $1-3.03 \%$ \\
Gedda & $1955[21]$ & 45 & ND & $1-3.7 \%$ \\
Lebowitz & $1963[23]$ & 62 & ND & $8-18 \%$ \\
Bonfiglio and Atwater & $1969[51]$ & 47 & ND & $2-3.2 \%$ \\
Gardner & $1972[34]$ & 142 & ND & $4-8.5 \%$ \\
With septic arthritis & & & & $8-5.6 \%$ \\
Without septic arthritis & & & & $5-3.5 \%$ \\
Russel and Ansell & $1972[52]$ & 17 & ND & $3-2.1 \%$ \\
Püschel & $1972[25]$ & 143 & $9-6 \%$ & $2-11.7 \%$ \\
\hline
\end{tabular}


Table continued...

\begin{tabular}{lllll}
\hline Authors & Reference,Year of Publication & $\begin{array}{l}\text { Autopsy } \\
\mathbf{n}=\end{array}$ & $\begin{array}{l}\text { Clinically recognized SI } \\
\mathbf{N}-\%\end{array}$ & $\begin{array}{l}\text { Mortality of sepsis } \\
\mathbf{N}-\%\end{array}$ \\
\hline Vroninks and mtsi. & $1973[45]$ & 62 & $2-3.2 \%$ & $3-4.8 \%$ \\
Eulderink** & $1976[26]$ & $\mathrm{III}$ & $\mathrm{ND}$ & $3-2.7 \%$ \\
Rainer et al. & $1978[47]$ & 79 & $\mathrm{ND}$ & $21-27 \%$ \\
Reilly et al. & $1990[53]$ & 63 & $\mathrm{ND}$ & $3-4.8 \%$ \\
Bély et al.** & $1992[54]$ & 100 & $\mathrm{ND}$ & $10-10 \%$ \\
Toyoshima et al.**** & $1993[55]$ & 1246 & $\mathrm{ND}$ & $52-4.2 \%$ \\
Suzuki et al. & $1994[27]$ & $8 \mathrm{I}$ & $\mathrm{ND}$ & $5-6.2 \%$ \\
Bély*** & present work & $16 \mathrm{I}$ & $\mathrm{II}-6.83 \%$ & $24-14.9 \%$ \\
With prulent arthritis & & & $6-3.7$ & $12-7.45 \%$ \\
Without prulent arthritis & & & $5-3.1 \%$ & $12-7.45 \%$ \\
\hline
\end{tabular}

Remarks to Table 7

ND No Data

*Endocarditic bacterial infection (I), or lethal purulent peritonitis (3) leading to death

** Lethal septic infection accompanied with purulent arthritis only

***All lethal septic infections with or without purulent arthritis

****Based on national mortality statistics of Japan without detailed histological analysis of organ involvement.

\section{Conclusion}

Vasculitis or amyloidosis may cause gastrointestinal complaints, diarrhea, erosions, and hemorrhages, even peptic ulcers with bleeding, perforation, peritonitis or lethal sepsis. Detailed histological study of a large autopsy population of RA supports and statistically confirms that $\mathrm{gU}$ or $\mathrm{dU}$ are independent phenomena in RA and their prevalence and mortality is not influenced by the leading complications of RA, e.g by A-SV or AAa. (Peptic ulcers - in agreement with the literatureare probably related to the therapy of $\mathrm{RA}$ ). $\mathrm{gU}$ or $\mathrm{dU}$ significantly increases the risk of lethal septic infections, but are independent of purulent arthritis (based on our previous study PA should be regarded a specific source of $\mathrm{SI}^{13}$ ).

\section{Acknowledgments}

None.

\section{Conflicts of interest}

Authors declare that there is no conflict of interest.

\section{References}

1. Farah D, Sturrock RD, Russell RI. Peptic ulcer in rheumatoid arthritis. Ann Rheum Dis. 1988;47(6):478-480.

2. Roth SH. Peptic ulcer in rheumatoid arthritis. Ann Rheum Dis. 1989;48(5):438-439.

3. Malone DE, McCormick DA, Daly L, et al. Peptic ulcer in rheumatoid arthritis-Intrinsic or related drug therapy? Rheumatology. 1986;25(4):342-344.

4. Griffin MR, Smalley WE. Drugs and ulcers: clues about mucosa protection from epidemiologic studies. $J$ Clin Gastroenterol. 1995;21(Suppl 1):113-119.

5. Kelly C, Hamilton J. Editorial. What kills patients with rheumatoid arthritis? Rheumatology. 2007;46(2):183-184

6. Pecora PG, Kaplan BP. Corticosteroids and ulcers: is there an association? Ann Pharmacother. 1996;30(7-8):870-972.
7. Cooke AR. Corticosteroids and peptic ulcer: is there a relationship? Am J Dig Dis. 1967;12(3):323-329.

8. Menguy R. Do corticosteroids cause peptic ulcer? Another point of view. Am J Dig Dis. 1967;12(7):749-751.

9. Mohr W. Chronische Gelenkentzündungen, Pathomorphologie In: Mohr (Ed.), Gelenkpathologie, historische Grundlagen, Ursachen und Entwicklungen von Gelenkleiden und ihre Pathomorphologie. 1st ed. Springer-Verlag: Berlin, Heidelberg, Germany; 2000. 334-335 p.

10. Fassbender HG. Rheumatoid arthritis in Pathology and pathobiology of rheumatic diseases. 2nd ed. Springer-Verlag: Berlin, Heidelberg, New York, Germany; 2002. 155-158 p.

11. Gardner DL. Rheumatoid arthritis: cell and tissue pathology, Alimentary system. In: Auckland, Gardner DL (Eds.), Pathological basis of the connective tissue diseases. 1st ed. Edward Arnold: London, UK; 1992. 501-502 p.

12. Arnett FC, Edworthy SM, Bloch DA, et al. The American Rheumatism Association 1987 revised criteria for the classification of rheumatoid arthritis. Arthritis Rheum. 1988;31:315-324.

13. Bély M, Apáthy Á. Clinical pathology of rheumatoid arthritis: Cause of death, lethal complications and associated diseases in rheumatoid arthritis. 1st ed. In: Bély M (Ed.), Akadémiai Kiadó: Budapest, Hungary; 2012. 1-440 p.

14. Romhányi G. Selective differentiation between amyloid and connective tissue structures based on the collagen specific topo-optical staining reaction with Congo red. Virchows Arch A Pathol Pathol Anat. 1971;354(3):209-222

15. Bély M, Makovitzky J. Sensitivity and Specificity of Congo red Staining According to Romhányi - Comparison with Puchtler's or Bennhold's Methods. Acta Histochem. 2006;108(3):175-180.

16. Bély M. Histochemical differential diagnosis and polarization optical analysis of amyloid and amyloidosis. Scientific World Journal. 2006;6:154-168

17. Lentner C. Statistical methods. In: Geigy scientific tables 8th revised and enlarged ed. Compiled by: Diem K, Seldrup, Ciba-Geigy Limited: Basle, Switzerland. 1982;2:227. 
18. Baggenstoss AH, Rosenberg EF. Visceral lesions associated with chronic infectious (rheumatoid) arthritis. Arch Path. 1943;35:503-516.

19. Rosenberg EF, Baggenstoss AH. The causes of death in thirty cases of rheumatoid arthritis. Ann Intern Med. 1944;20(1):903-919.

20. Young D, Schwedel JB. The heart in rheumatoid arthritis. Am Heart J. 1994;28:1-23.

21. Teilum G, Lindahl A. Frequency and significance of amyloid changes in rheumatoid arthritis. Acta Med Scand. 1954;149:449-455.

22. Gedda PO. On amyloidosis and other causes of death in rheumatoid arthritis. Acta Med Scand. 1955;60:443-452.

23. Sinclair RJG, Cruickshank B. A clinical and pathological study of sixteen cases of rheumatoid arthritis with extensive visceral involvement (Rheumatoid disease). Q J Med. 1956;25(99):313-332.

24. Lebowitz WB. The heart in rheumatoid arthritis (Rheumatoid disease).A clinical and pathological study of sixty-two cases. Ann Intern Med. 1963;58(6):102-123.

25. Ozdemir AI, Wright JR, Calkins E. Influence of rheumatoid arthritis on amyloidosis of aging. Comparison of 47 rheumatoid patients with 47 controls mached for age and sex. N Eng J Med. 1971;285(10):534-538.

26. Püschel W. Sektionsstatistische Untersuchungen bei der RheumatoidArthritis. Dtsch Gesundheitwesen. 1972;27:754-756.

27. Eulderink F. Doodsoorzak: rheumatoide arthritis. Ned T Geneesk. 1976; 120:357-363.

28. Suzuki A, Ohosone Y, Obana M, et al. Cause of death in 81 autopsied patients with rheumatoid arthritis. $J$ Rheumatol. 1994;21(1):33-36.

29. Bély M, Apáthy Ágnes. Prevalence and mortality of gastric and duodenal ulcers in rheumatoid arthritis-A retrospective clinicopathologic study of 161 autopsy patients. Wien Klin Wochenschr. 2014;126(Suppl 5):207.

30. Bély M, Apáthy Ágnes. Present study.

31. Cruickshank B. The arteritis of rheumatoid arthritis. Ann Rheum Dis. 1954;13(2):136-146.

32. Cruickshank B. Heart lesions in rheumatoid disease. J Pathol Bacteriol. 1958;76(1):223-240.

33. Sokoloff L. Cardiac involvement in rheumatoid arthritis and allied disorders: current concepts. Mod Concepts of Cardiovas Dis. 1964;33:847-850.

34. Karten I. Arteritis, myocardial infarction, and rheumatoid arthritis. JAMA. 1969;210(9):1717-1720.

35. Gardner DL. Causes of death in the pathology of rheumatoid arthritis. Edward Arnold: London; 1972. 183-197 p

36. Davis RF, Engleman EG. Incidence of myocardial infarction in patients with rheumatoid arthritis. Arthritis and Rheumatism. 1974;17(5):527-533.

37. Albada-Kuipers vGA, Bruijn JA, Westedt ML, et al. Coronary arteritis complicating rheumatoid arthritis. Annals of the Rheumatic Diseases. 1986;45:963-965.
38. Boers M, Croonen AM, Dijkmans BA, et al. Renal finding in rheumatoid arthritis: clinical aspect of 132 necropsies. Ann Rheum Dis. 1987;46(9):658-663

39. Bély M. Krankheitsmodifizierende Faktoren bei chronischer Polyarthritis: Über Zusammenhänge zwischen generalisierter Vaskulitis, sekundärer Amyloidose, septischen Infektionen und Auftreten von miliaren epitheloidzelligen Granulomen. D.Sc. Thesis, Budapest; 1993.

40. Bély M, Apáthy Á. Lethal complications and associated diseases of rheumatoid arthritis-a retrospective clinicopathologic study of 234 autopsy patients. Orv Hetil. 2006;147(23):1063-1076.

41. Bayles TB. Rheumatoid arthritis and rheumatic heart disease in autopsied cases. Am J Med Sci. 1943;205:42-48.

42. Unger PN, Zuckerbrod M, Beck GJ, et al. Amyloidosis in rheumatoid arthritis. Am J Med Sci. 1958;216:51-56.

43. Missen GAK, Taylor JD. Amyloidosis in rheumatoid arthritis. J Path Bact. 1956;71(1):179-192.

44. Cohen AS. Amyloidosis associated with rheumatoid arthritis. Med Clin N Am. 1968;52:643-653.

45. Gritsman NN. Morfologicheskaya kharakteristika porazheniya pri infektsionnom nespetsificheskom poliartrite. (Morphological characteristics of affection of the heart in infectious nonspecific polyarthritis (rheumatoid arthritis) Archiv patologii. 1969;31:49-53.

46. Vroninks $\mathrm{Ph}$, Cats A, Eulderink F, et al. Hartafwijkingen bij rheumatide arthritis, in het bijzonder pericarditis. Ned T Geneesk. 1973;117:10-17.

47. Hajzok O, Tomik F, Hajzoková M. Amyloidosis in rheumatoid arthritis. A study of 48 histologically confirmed cases. Z Rheumatol. 1976;35(910):356-362.

48. Rainer F, Klein G, Schmid P, et al. Untersuchungen über Art und Häufigkeit der Todesursachen bei chronischer Polyarthritis. Z Rheumatol. 1978;37:335-341.

49. Boers M, Croonen AM, Dijkmans BA, et al. Renal finding in rheumatoid arthritis: clinical aspect of 132 necropsies. Ann Rheum Dis. 1987;46(9):658-663.

50. Bély M. Sekundäre Amyloidose bei chronischer Polyarthritis. Zentralbl allg Pathol pathol Anat. 1990;136:337-357.

51. Bywaters EGL. The relation between heart and joint disease including "rheumatoid heart disease" and chronic post-rheumatic arthritis (type Jaccoud). Br Heart J. 1950;12(2):101-131.

52. Bonfigloio T, Atwater EC. Heart disease in patients with seropositive rheumatoid arthritis. Arch Intern Med. 1969;124(6):714-719.

53. Russel AS, Ansell BM. Septic arthritis. Ann Rheum Dis. 1972;31:40-44.

54. Reilly PA, Cosh JA, Maddison PJ, et al. Mortality and survival in rheumatoid arthritis: a 25 year prospective study of 100 patients. Ann Rheum Dis. 1990;49(6):363-369.

55. Bély M, Apáthy Á, Zsíros I. Septische Komplikationen bei chronischer Polyarthritis. Rheuma. 1992;12:18-26.

56. Toyoshima H, Kusaba T, Yamaguchi M. Cause of death in autopsied RA patients. Ryumachi. 1993;33(3):209-214. 